\title{
Some Characteristics of the Dutch System for Compensation of Damage
}

\author{
by John H. Wansink, Robert A. Salomons and Theo Kremer*
}

\section{Introduction}

This paper provides primarily some basic information on the Dutch legal system for compensating damage as well as the role therein of private liability insurance and social security. Furthermore the basic elements of tort litigation and the allocation of the cost of litigation and legal expenses are described.

\section{Liability law}

\subsection{The ground of liability}

In Dutch law liability is, in general, based on fault. In this system there is no general shift from fault to presumptive negligence. Any degree of fault is sufficient for the existence of liability.

This will not change in the New Civil Code which is expected to become effective in 1992. At most you could say that jurisprudence objectifies and depreciates the conception of fault.

The New Civil Code will impose strict liability on:

- parents for their children under 14 ;

- independent contractors;

- people being represented for their representatives;

- mentally handicapped (any lack of fault does not preclude them from being liable);

- owners of faulty movable property used in conducting a business;

- owners of animals.

These strict liabilities do not yet exist in current law. There is one exception: strict liability for animals was "introduced" by the Supreme Court of the Netherlands in 1980 , in anticipation of the New Civil Code.

\footnotetext{
* Professor Dr. Wansink teaches insurance law at the Erasmus University in Rotterdam; Mr. Salomons is Legal Advisor of the Delta Lloyd Insurance Company in Amsterdam; Mr. Kremer is Legal Advisor of the Nationale Nederlanden Insurance Company in The Hague.
} 
Strict liability does already exist in present law for :

- subordinates;

- buildings;

- motor vehicles (in a few cases specifically mentioned in the law).

\subsection{The onus of proof}

There is a general rule that the onus of proof lies with the plaintiff: so, in general, the plaintiff has to give evidence for all the facts which are the basis of his claim. The defendant has the right to give counter evidence by proving that the given facts are untrue or that they must be doubted, or to give relevant new facts. The onus of proof may be partitioned by the judge on the bases of reasonableness and fairness. This is increasingly done so in favour of the injured party in cases of products liability; the most important consideration in this respect is that the injured party has increasingly less understanding of services rendered and products delivered to him to let him carry the whole onus of proof.

\subsection{Causal connection}

The nature of the damage may present a difference as to the question whether the person causing the damage can be blamed for the damage. For instance, sometimes bodily injury is imputed sooner on somebody than material damage. So, this difference plays a role as to the causal connection.

Damage must be compensated completely, in principle. However, if the damage is too remotely related to the fact causing the damage, there will be no liability on account of the lack of adequate causal connection.

Contrary to the present Civil Code, the New Civil Code states a specific rule for the socalled alternative causality:

Art. 6.1.9.4a

"If the damage may be the result of two or more events for each of which another person is liable, and if it has been established that the damage has been caused by at least one of these events, then it is incumbent on any of these persons to make a compensation for the damage, unless he proves the damage is not a consequence of an event for which he himself is liable."

To the best of our knowledge there is no practical experience with "alternative liability", "concert of action", "enterprise liability", etc.

\subsection{Contributory negligence}

There is a general rule which implies that the injured party's own fault relieves the liable party from his responsibility either completely or partly (unless the "own fault" shrinks into insignificance compared with the fault of the person causing the event).

\subsection{Compensation and mitigation of indemnity}

As said above damage must be compensated completely, in principle. However, in personal injury cases, articles 1406 and 1407 of the Civil Code entitle the Court to limit the amount of indemnity according to the financial positions of the claimant and the defendant and to other circumstances of the case. Moreover, this limitation is not allowed in so far as the amount of indemnity is covered by a liability insurance. 
The bill for the New Civil Code provides a wider power to mitigate. It covers all kinds of liability (tort and contract, for example) and all kinds of damage. On the other hand, this mitigation is not allowed in so far as the amount for which the defendant is liable is covered or should be covered compulsorily by liability insurance (article 6.1.9.12a New Civil Code).

In addition to the above power, the bill for the New Civil Code provides a statutory limitation of liability in article 6.1.9.12b: in order that the extent of liability does not exceed the amount that can reasonably be covered by an insurance contract, the amount beyond which the liability shall not rise may be fixed by enactment. Separate amounts may be fixed according to the nature of the incident, the kind of damage (bodily injury, property damage, non-pecuniary losses) and the nature of liability (negligence, strict liability, contractual liability).

Compensation for non-material damage (mainly for pain and suffering) will, in principle, be allowed only in a number of cases mentioned in the law and in jurisprudence:

- bodily injury, art. $1407 \mathrm{CC}$ (only to the injured person himself)

- insult, art. 1408-1416 CC.

The non-material damage is established ex aequo et bono and is not dependent on limits in the law. Punitive damages are unknown in Holland.

\section{Liability insurance}

\subsection{General liability insurance}

Generally speaking general liability insurance has developed since World War II from a public liability insurance which hardly covered contractual liability or none at all, to a general liability insurance, which is characterised by an "open" basic cover for any liability for damage suffered by third parties. The borderline of this "open" cover should be found in the subsequent general policy conditions.

Clauses which effect both the insurance for private persons and for business are the exclusion of damage to property in the insured's custody or control as well as the limitation of coverage by the nature of damage (property damage, bodily injury), by the insured capacity, by time (loss occurrence, claims made) and by amount (limit per event, serial claims clause, aggregate limit).

As far as public liability insurance is concerned reference should be made to the socalled trade risk which underwriters consider uninsurable on account of technical grounds, and to the clauses in which this risk is excluded: the exclusion of liability assumed by the insured by agreement which would not otherwise have attached and the exclusion of damage to goods sold, supplied or repaired by the insured, as well as of damage and expenses in relation to the replacement, repair or improvement of such goods, or redoing the agreed work in full or partly.

To indicate roughly the premium charged for coverage of the risk of public liability, including products liability and employers' liability, the following data:

- dfls. 5000,- for a contractor with a turn-over of dfls. 5 million and a total amount of wagepayments of dfls. 1 million;

- dfls. 100,- for a grocer with an turn-over of dfls. 400.000,-- 
In both cases the sum insured amounts to dfls. 1 million per event in excess of a deductible of dfls. $1.000,-$. Generally speaking the sum insured for middle size companies varies between dfls. 1 and 2,5 million per event.

\section{(a) Products liability}

Part of the system as described roughly above, is that the risk of products liability is included in the standard cover. However in general this cover is confined to the risk attached to products explicitly mentioned in the policy. A more restricted coverage applies in case of export to the United States and Canada.

\section{(b) Employers' liability}

Part of the system as described above, is also that the risk of employers' contractual liability, based on article $1638 \mathrm{x}$ of the Civil Code, is included in the standard coverage. It should be mentioned that the exclusion clause for the so-called non-sudden risk of environmental impairment does not apply to industrial accidents or occupational diseases even when noxious materials were involved.

\section{(c) Accidents caused by motor vehicles}

The risk of liability for accidents caused by motor vehicles is explicitly excluded from the general public liability policy. It is considered a special risk which should be dealt with under a special insurance and - besides this - the coverage for this risk is governed by a system of compulsory insurance pursuant to the Liability Insurance for Motor Vehicles Act (WAM).

\section{(d) Liability for pollution damage}

Another risk which is not fully covered by the general liability insurance is the risk of liability for pollution damage. The introduction of the Polluter Pays Principle resulted in 1971 in a recommendation of the Dutch Association of General Liability Insurers (AAV) to incorporate the following exclusion in the public liability insurance: "The cover excludes damage in connection with pollution and/or impairment of soil, air or water, unless such pollution and/or impairment is the result of a sudden and unexpected occurrence". So, from then on the environmental risk was no longer covered, unless the insured could prove that the damage was the result of a sudden, unexpected discharge or emission (think of Seveso, Bhopal, Sandoz). In other words, the non-accidental industrial discharge or emission (the so-called non-sudden risk) was excluded. As there is some misunderstanding about this, it is a good thing to emphasize that it is not a decisive factor whether suddenly released substances are causing the damage by gradual effect.

\subsection{Liability insurance for motor vehicles}

As mentioned above, the liability insurance for motor vehicles is governed by the socalled WAM-legislation, enacted in 1965 to incorporate Benelux law and E.E.C. directives regarding insurance for motor vehicles (see for the latest version Staatsblad 1987, no. 500). The WAM is based upon the Benelux Treaty signed on January 7, 1955 and the E.E.C. directive of December 19, 1972 (E.E.C. Publications 1973, 175) and December 30, 1983 (E.E.C. Publications 1984, L8/17).

\section{(a) Compulsory Insurance}

Pursuant to the WAM, every person in possession of a motor vehicle must insure it. The insurance coverage must include the liability of the possessor, every holder and driver 
and the passengers for damage to persons or goods caused by the motor vehicle in a country or region designated in the WAM.

Compulsory coverage is limited to liability for damage caused by the motor vehicle while in traffic (Cfr. Benelux Court of Justice October 23, 1984, NJ 1986, 458). Since January 1, 1988, minimum coverage of dfls. 2 million per event is required for private motor vehicles. However, on a voluntary basis a higher sum insured is available up to dfls. 5 million per event. Certain exceptions are provided for, inter alia, the State and acknowledged conscientious objectors.

The annual premium for a VW (Rabbit) Golf amounts to dfls. 1003,- and for a Ford Scorpio to dfls. $1535,-$ in both cases without any no-claim rebate. The maximum rebate (after ten years free of claims for compensation) is $75 \%$ of the basic premium.

(b) The direct right of action of an injured party against a WAM insurer

The protection of victims is a fundamental policy of the WAM. Therefore, victims are granted a direct right of action against the WAM insurer (section 6), which creates a debtorcreditor relationship between him and the insurer. Thus, the insolvency or bankruptcy of the insured does not affect the relationship between the injured party and the insurer. However, there is a limited number of so-called permissible exceptions, which are enforceable as to the injured party as well. These exceptions, expressly mentioned in the WAM, may relate to the (1) liability of thieves of the vehicle insured, (2) liability for damage to goods carried by vehicles that cause such damage, (3) liability for damage to the insured, possessor, holder and driver of the motor vehicle, and (4) bodily injuries of spouses and certain relatives of persons mentioned under 3 recoverable by the injured party from a firstparty insurance or social security fund.

\section{(c) Relationship between Insured and Insurer}

Pursuant to the WAM, the insurer is still free to contract for any exclusion and/or restriction, although - according to section 11 - they do not affect the rights of the injured third party. Since the coverage for injured parties is fixed pursuant to section 11 , and section 15 provides a right of recourse to the insurer for all sums paid by him which he would not have been liable to pay but for the provision of section 11, commentators have expressed the fear that the insureds' rights are being compromised to an unacceptable extent.

In practice, this fear has not been realized due to the fact that insurers have restricted these exceptions to a few well accepted issues such as intentionally caused damage, use of motor vehicle in a manner contrary to permissable use (eg. carriage of persons for payment), valid driver's license not in possession or revoked, damage caused by non-authorized driver. Further protection of the insured is provided by the principle of "relativity", which applies in cases where the insured can show that the circumstances designated in exclusions, such as those mentioned above, occurred without his knowledge or against his will.

Finally, it should be mentioned that the classic clause, which excludes coverage for damage caused while driving under the influence of alcohol, is no longer used.

(d) The Motor Vehicle Guaranty Fund (Waarborgfonds Motorrijtuigen)

Additional protection for victims is provided by the Motor Vehicle Guaranty Fund (Waarborgfonds Motorrijtuigen ("the Fund"). WAM-insurers are obligated to pay into the Fund on a per insured motor vehicle basis. The purpose of the Fund is to guarantee 
coverage in cases where according to general civil law it has been determined that civil liability for damage sustained exists, but an appeal to a WAM insurer is not possible:

- when the identity of the person liable for the damage cannot be reasonably ascertained (hit-and-run cases and cases of chain collision, where there is liability within the closed group of persons involved but the identity of the actual tortfeasor cannot be ascertained, see Supreme Court May 23, 1980, NJ 1981, 1);

- when the liable party has not complied with the obligation to be insured;

- when the damage results from an act or omission by one who has gained possession of the motor vehicle by means of theft or an act of violence or by someone who, knowing of such theft or violent act, uses the motor vehicle without valid reason, and thus, no insurer is liable;

- in the case of the insolvency of the insurer; and

- when an exemption from the duty to insure has been granted to the person liable for the damage (e.g. conscientious objectors).

The Fund is a second line of protection; thus, appeals to the Fund are permissible only if the injured party can show that he has summoned all known potentially liable persons and that there is prima facie evidence that the damage will not be recoverable from them. Also, as of January 1988, a claim on the Fund for compensation of property damage is subject to a dfls. 200.00 "deductible".

In 1986 the Fund received 41.500 claims, of which 29.500 were sustained, resulting in a total amount of payments of dfls. 56 million.

(e) New developments

Due to dissatisfaction with certain aspects of the current system for compensation of traffic accident damage, the Minister of Justice in 1974 formed a commission composed of various authorities, insurers and the "ANWB" (RAC) to investigate possible alternatives.

In two reports the commission has recommended changes with respect to both property damage and bodily injury, which have not been implemented. With respect to bodily injury, the commission recommended in its report of 1978 two alternative systems: the institution of a "first party" motor insurance, or the introduction of absolute liability for motor accidents; in both cases in combination with the abolition of the rights of recourse to the social security funds. With respect to property damage, the commission recommended in its report of 1980 the Barema-system, used in Belgium, in which the assessment of fault is fixed for the most frequent types of motor vehicle mishaps.

Up to now both reports have not led to any change in legislation.

\subsection{Environmental impairment liability insurance}

Since March 1, 1985, potential polluters may obtain from the so-called MAS-pool, which is composed of a large number of insurance companies, a wider coverage for the risks of liability for environmental damage. The coverage is broader than in the past in that sense that the coverage is not limited to pollution or invironmental impairment that results from a sudden and unexpected occurrence. To this end the public liability policy (AVB policy) has been extended by a section entitled "Environmental Impairment Liability". In principle 
this section provides limited coverage for damage resulting from the release of noxious substance directly from an insured site, irrespective of whether this release is sudden and unexpected.

The most important aspects of this coverage are the following:

\section{(a) Limits of indemnity}

There is a limit per claim, being the maximum for what the insurer will pay in total in connection with one impairment (emission) or imminent impairment of the environment as to all claims, including interest, extrajudicial expenses, legal expenses and cost of proceedings as well as all claims for salvage costs for the account of the insured. In addition, the above mentioned chain of pollutions (interrupted or not) shall be considered one environmental impairment within the context of the policy.

The amount of the sum insured varies between dfls. 1 and 5 million per polluting event. However, this sum may never exceed the sum insured of the applicable general liability coverage and in addition to this the coverage is always limited to an annual aggregate of twice the sum insured per polluting event with an absolute maximum of dfls. 5 million.

\section{(b) Time limits}

As in the event of gradual effect of environmental pollution it can hardly ever be established exactly when the damage arose, the insurers have not chosen the so-called "loss occurrence principle" as the system for limitation of the coverage by time, as is common practice when insuring the general public liability risks, but have instead based the special environmental cover on the "claims-made principle": in principle the polluters' liability is covered if the third party's claim for compensation is received by the insurer during the term of the insurance contract. For the insurer this system holds the advantage that it does not have to provide cover for claims received a long time after the policy was terminated and the last premium has been paid. On the other hand the system implies that the termination of the insurance means that the insured has no longer any right of compensation for claims reported after such termination. To mitigate this effect the coverage contains, for a number of cases wherein the policy is cancelled by the insurer for reasons other than the insured's bad faith, an irrevocable offer to cover the so-called run-off risk for a period of one year.

\section{(c) The concept of damage}

Apart from bodily injury the general public liability policy also covers property damage, but only if it concerns physical injury to, destruction, or loss of tangible property belonging to third parties. This concept of property damage is too restricted for the specific environmental impairment liability cover. In a number of cases there would be no cover at all for damage that is very well imaginable, particularly in the event of environmental pollution. Think of damage suffered by a hotel keeper because excessive stench makes it impossible for him to run his - physically undamaged - hotel. This gap is filled by the new coverage of "pure" economic loss, including the pollution or contamination of any surface water as well as the loss of economic use of tangible property not physically injured etc. including any consequent damage.

(d) The so-called run-in risk and environmental damage from the past

The choice of the claims-made principle for the limitation of coverage by time implies that, during the term of the insurance, the insurer could be faced with environmental claims 
which, as to unlawful acts and omissions with regard to management of the environment, may be traced back to a time when society was dealing with the environment under the rule "everyone for himself and the environment for all of us". The insurance of this risk, the extent of which can still hardly be estimated, has a time bomb effect which might jeopardize the continuity of the new cover. For this reason the cover contains a standard clause excluding damage resulting from an environmental impairment which is caused by the insured's acts or omissions prior to the inception of the insurance.

\section{(e) Unlawful/warranted emission initiated by the management of a company}

One of the major problems in fighting pollution is that, in an expense point of view, it is often cheaper for companies to discharge noxious substances illegally instead of neutralizing them or disposing of them in a lawful way. Granting cover for such actions would not be justifiable towards the collectivity of bona fide insureds. Moreover, this would reward this socially unacceptable behaviour, whereas all efforts are aimed at suppressing it. Therefore the cover excludes liability for damage resulting from an act or omission in violation of any governmental rule with regard to the environment, if it takes place by order or consent of any member of the board or the management of a company, or any other employee of the company who has been charged with a special responsibility for the observation of such regulations.

The possibility also exists that a company discharges gradually and, in doing so, inflicts damage upon third parties. It will escape from a judicial injunction if the judge is of the opinion that this activity should be tolerated for the common good or - under article 6.3.1.5 of the New Civ. C. - on account of major social interest and the polluter assumes responsibility for the damage for his own account. The crux of the matter for the insurers is the fact that an insured, faced with an action for an injunction, is left with the following choice : either stop the activities and/or clean-up, or request permission to continue the activities. If the latter is the case, the insured will consciously accept any future third party claim on his own account, and he will include the cost of these claims in the cost price of his activities. Insurers consider the obligation to pay such future claims a risk that should remain for the account of the polluter (business risk).

\section{(f) Salvage costs/clean-up costs}

As this cover is primarily aimed at the protection of third parties exposed to the risk of pollution in the vicinity of the insured company, there is explicitly no coverage for clean-up costs at an insured site. However there is one exception, namely if and insofar as these clean-up costs are salvage costs within the meaning of article 283 of the Com. C. This is in line with the primary aim of the cover as mentioned above, as this section refers to costs connected with measures taken by or on behalf of the insured, which are reasonably required to avert the imminent danger of third parties suffering damage for which - on the happening thereof - the insured would be responsible and for which the insurance provides cover, or - if the damage has materialised - to limit such damage as much as possible.

\subsection{Liability insurance for medical care in hospitals}

A number of insurance companies have set up an insurance pool and introduced the socalled MAR-policy, particularly designed to cover the overall risk of liability for medical malpractice in a hospital or medical center. 
The coverage applies to everyone who provides medical care as a doctor or nurse within the walls of the hospital, irrespective of whether he or she is employed by the hospital or not. This collective cover is advantageous for the patient, particularly in cases where the medical treatment is done by a team of doctors and nurses and someone has made a fault but it is not clear who actually is to blame. To collect the insurance money it is sufficient to determine that someone within the team has made an "avoidable" fault. The average sum insured varies between dfls. 2,5 and 5 million. The maximum sum insured per event as well as the aggregate limit is dfls. 12,5 million.

\subsection{The legal relationship between the victim and the liability insurer; compulsory insurance}

Apart from the motor vehicle liability insurance and the huntsman's insurance the victim has no direct right of action against the insurer which creates a debtor-creditor relationship between him and that insurer. In other words, current law, if it concerns general liability insurance, does not supply adequate guaranty that the insurance money should eventually be for the victim's benefit, even in case of the insured's insolvency (bankruptcy). One can doubt whether this will be different under the regime of the New Civil Code, wherein article 3.10.3.15 attributes a preference for the victim in respect of the insured's claim against the insurer.

The same special legislation which grants the victim a direct right of action against the insurer in case of motor vehicle and huntsman's liability insurance, provides the compulsory character of these types of liability insurance. Compulsory liability insurance by law is restricted to these two types of insurance.

\section{Social security benefits}

\subsection{Introduction}

The Dutch system of social security and provisions can be divided into three categories:

a. employed persons insurance schemes

b. national insurance schemes

c. social benefits.

\subsection{Employed persons insurance schemes}

\begin{tabular}{lll} 
Act & Coverage & Benefits/Provisions \\
\hline $\begin{array}{l}\text { Unemployment Insurance Act } \\
\text { (WW) }\end{array}$ & all workers & $\begin{array}{l}\text { unemployment benefit : } \\
70 \% \text { of daily wages for } 26 \text { weeks } \\
\text { at the most }\end{array}$ \\
$\begin{array}{lll}\text { Sickness Benefits Act } \\
\text { (ZW) }\end{array}$ & all workers & $\begin{array}{l}\text { sickness benefit: } 70 \% \text { of daily wages } \\
\text { for } 52 \text { weeks at the most }\end{array}$ \\
$\begin{array}{l}\text { Disablement Insurance Act } \\
\text { (WAO) }\end{array}$ & all workers & $\begin{array}{l}\text { disablement benefit : } 14 \%-70 \% \text { of } \\
\text { daily wages according to the degree } \\
\text { of incapacity }(15 \% \text { or more })\end{array}$
\end{tabular}


Health Insurance Act $(\mathrm{ZFW})$ *

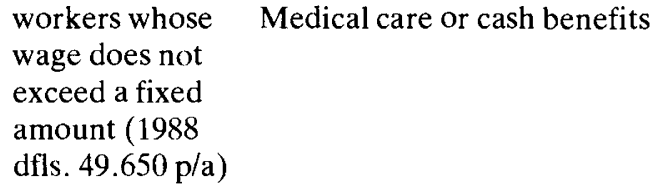

* Of the total number of insureds covered against medical costs, approximately two thirds are covered by the ZFW (Health Insurance Act), whereas the remaining one third are voluntarily covered under private health insurance.

\subsection{National Insurance Schemes}

\begin{tabular}{lll} 
Act & Coverage & Benefits/Provisions \\
\hline $\begin{array}{l}\text { Exceptional Medical } \\
\text { Expenses Act (AWBZ) }\end{array}$ & all residents & $\begin{array}{l}\text { prolonged medical treatment, } \\
\text { nursing and care }\end{array}$ \\
$\begin{array}{l}\text { General Disablement } \\
\text { Benefits Act (AAW) }\end{array}$ & all residents & $\begin{array}{l}\text { disablement beneftit }: 21 \%-70 \% \text { of } \\
\text { the basis according to the degree of } \\
\text { the incapacity (25\% or more) } \\
\text { - provisions (benefits in kind) }\end{array}$
\end{tabular}

General Family Allowance Act all residents $(\mathrm{AKW})$

General Old Age Pensions Act all residents (AOW)

General Widows and Orphans Act all residents $(\mathrm{AWW})$ family allowance; contributions are regulated by law

old-age pension benefit from age 65 ; contributions are regulated by law

widows and orphans pensions; contributions are regulated by law

For an elaboration of the employed persons and national insurance schemes, reference is made to the Appendix.

\subsection{Social provisions}

Act

Coverage

Act on income provisions for older and partially

all workers disabled workers (IOAW)

Act on income provisions for older and partially disabled formerly self-employed (IOAZ)

National Assistance Act (ABW)

certain groups only

Regulations on unemployment assistance (RWW)

all residents

all residents

In general the amount of the above benefits is coupled to the net minimum income (1988: dfls. $1500,-\mathrm{p} / \mathrm{m}$ ) and relates to the so-called "social minimum applicable to the persons". 


\subsection{Recourse}

(a) Health insurance funds.

The health insurance funds have, within the scope of articles $83 b$ and $83 c$ of the Health Insurance Act, a direct right of recourse for the benefits paid.

(b) Industrial insurance boards.

The industrial insurance boards have a direct right of recourse for benefits (provisions of income) paid to the employed and semi-employed within the scope of articles $52 \mathrm{a}$ and $52 \mathrm{~b}$ of the Sickness Benefits Act and articles 90 and 91 of the Disablement Insurance Act.

(c) National Insurance Schemes and the Benefits Act.

No right of recourse against a responsible third party exists for benefits and provisions supplied under National Insurance Schemes or social provisions.

(d) Unemployment Insurance.

Under the (new) Unemployment Insurance Act there is no right of recourse against a responsible third party.

\section{Litigation}

\subsection{Introduction}

In general a claim for compensation of damage will be brought before the district court (arrondissementsrechtbank); there are 19 district courts in Holland. Exceptions must be made for claims with a pecuniary interest of less than dfls. 5.000,-- and claims with respect to contracts of employment, especially those regarding article $1638 \mathrm{X}$ of the Civil Code (i.e. employer's liability for industrial accidents). Cases of this nature are brought before the magistrates court (kantongerecht); there is one in most medium-sized towns in Holland. Cases are judged by one magistrate.

Holland does not have the system in which the civil proceedings are automatically coupled to a possible criminal action. The possibility to join the civil action with the criminal action exists only if the civil claim does not exceed the amount of dfls. 1.5000,--

\subsection{Procedure before the district court (arrondissementsrechtbank)}

District Courts consist normally of 3 magistrates. However, in recent years there is an increasing tendency - especially in the less complex cases - towards cases being tried by one judge only (the so-called unus-iudex administration of justice). The jury system is unknown in Holland.

Litigation before the district court takes approximately two years. If a party lodges an appeal with the court of appeal (Gerechtshof) and subsequently takes the case to the Supreme Court (Hoge Raad) the entire prodecure takes at least 6 years.

The procedure in essence is conducted in writing by means of submittance of statements by the parties involved. In addition to this witnesses can be called. Furthermore it is possible for parties to verbally elucidate their point of view (by pleading).

In urgent cases it is possible to obtain a ruling at short notice through an injunction. These rulings are made by one magistrate. Generally an injuction will be sought in order to obtain temporary provisions (for instance an advance payment). The case itself must then be decided in the normal courts (the so-called elementary procedure "bodemprocedure"). 


\subsection{Legal representation}

With the exception of proceedings before the magistrates courts, the system of compulsory legal representation is applicable in Holland. This principle entails that parties cannot appear in a procedure unless they are represented by a lawyer who executes all procedural activities on their behalf. There are at present approximately 5400 lawyers professionally active in this field in Holland. However, according to French statistics (Gazette du Palais, 2nd January 1982, page 7) only $1 \%$ of the claims resulting from traffic accidents in Holland end up in court. This is an indication that in Holland many cases are settled out of court.

\subsection{Legal expenses}

In principle each party has to bear its own costs. These costs consist mainly of the lawyer's fees and the costs of submitting evidence (especially compensation to witnesses and the remuneration of experts). The lawyer's fee is determined upon the amount of the hours spent and the financial interest of the case. The principle of no cure, no pay does not apply. In addition, there are also court fees.

It is standard practice that the losing party is ordered to pay the costs incurred by the opponent. However, reality proves that this compensation - determined by the court - is (often) insufficient to meet the actual expenses incurred.

For the poor and insolvent there are provisions to undertake legal action fully or partially free of charge: The State pays for their legal expenses on a statutory rate. However, this system of legal aid does not include the reimbursement of the court fee and the legal expenses imposed by the court on the losing party. To be entitled to legal aid the claimant has to prove that he has a reasonable interest in litigation.

\subsection{Legal aid insurance}

In Holland several insurance companies offer legal assistance cover. This form of insurance originally applied especially to traffic accidents, but has recently found a more general application. The "domestic legal aid insurance" provides coverage for a variety of situations, for example disputes about personal liability, contracts, labour and insurance law.

Within the framework of cover and insured sums, this insurance gives a complete cover for the costs of litigation, such as lawyer's and experts' fees. Furthermore the insurance also covers the opponent's costs if and as far as the insured is held liable for these by a court of law. In granting legal assistance the insurers generally require that the insured must have a reasonable chance to win his case.

It is estimated that $15 \%$ of Dutch families have a legal aid insurance. Furthermore there are other bodies offering legal assistance, for example Unions, Citizens' Advice Bureau and Consumer Organisations such as the ANWB (the Royal Dutch Touring Club).

\section{APPENDIX}

\section{Social Security}

\section{Unemployment}

Unemployment Insurance Act (NWW)

The object of the new act, which came into effect on 1 January 1987, is to insure workers and those in an equal position against loss of income as a result of unemployment. 
Furthermore employees who are not unemployed may claim benefit under this act if their employers are not in a position to pay their wages.

In general all employed persons are insured including, for example outworkers and sales representatives.

Not insured are persons aged 65 or over and domestic staff working less than three days a week in a private household.

The act provides three kinds of benefits:

1. basic benefit for a period of six months;

2. extended benefit for four years and six months at the most;

3. continued benefit for one year at the most.

The amount of benefit is $70 \%$ of the lastearned wage which has a certain maximum.

The period of benefit depends on the claiman's age and labour history. A person who during a period of 12 months prior to his unemployment worked for at least 26 weeks is in general entitled to benefit for six months ("26-weken-eis"). A person is entitled to extended benefit if during five years priors to his unemployment he worked for at least three years ("3-uit-5-eis"). The period of benefit depends on the labour history. The period during which a person has supported one or more children younger than twelve is included in the labour history, either half or in full. If the above conditions are complied with the total period of benefit is as follows:

$\begin{array}{ll}\text { Labour history } & \text { Total period of benefit } \\ 0-5 \text { years } & 6 \text { months } \\ 5-10 \text { years } & 9 \text { months } \\ 10-15 \text { years } & 1 \text { year } \\ 15-20 \text { years } & 1 \text { year and six months } \\ 20-25 \text { years } & 2 \text { years } \\ 26-30 \text { years } & 2 \text { years and six months } \\ 30-35 \text { years } & 3 \text { years } \\ 35-40 \text { years } & 4 \text { years } \\ 40 \text { years and more: } & 5 \text { years }\end{array}$

After expiry of the extended benefit continued benefit may be claimed if the unemployment continues. This benefit is paid for one year and amounts to $70 \%$ of the minimum wage. If the benefit is below the beneficiary's social minimum supplementary benefit under the Supplementary Benefits Act ("Toeslagenwet") may be requested from the professional association.

From the benefit certain amounts may be deducted such as earnings in connection with loss of income or retirement pensions. In some cases employees are not entitled to a benefit.

If the - unemployed - benefit recipient fails to satisfy the conditions set forth in the Unemployment Insurance Act, certain sanctions may be applied by the professional association. Contributions are equally divided among employers and employees. 
Provision of Income for Senior and partly Disabled Unemployed Workers Act (IOAW)

This act became operative on 1 January 1987 together with the new Unemployment Insurance Act. As its name implies the act insures senior and partly disabled unemployed persons. After expiry of the unemployment benefit IOAW-benefit may be requested from the Municipal Social Service ("Sociale Dienst").

Entitled to IOAW-benefit are those unemployed persons who are partially disabled regardless of their age or who became unemployed after the age of 50 . Since the act is implemented by the municipalities it will not be discussed further.

\section{Sickness}

\section{Sickness Benefits Insurance Act (ZW)}

The act insures workers and those with equal rights against loss of wages as a result of sickness and infirmity and also provides maternity allowance. If a beneficiary dies, a death grant is paid to the dependants. The employer pays the contribution to the professional association. However, as a rule he may not deduct more than $1 \%$ from the wages.

The benefit is paid for a maximum of 52 weeks and amounts to at least $70 \%$ of the daily wage, i. e. the average salary the worker could have earned per day. If an employee is taken ill he has to notify his employer who in turn will notify the professional association. If so desired, the professional association arranges for a medical adviser to establish whether the claimant is unfit to perform his normal duties and whether he is entitled to benefit. As a rule the benefit is paid by the employer but it can be paid directly to the employee. To obtain and keep a benefit an employee has to satisfy a number of conditions.

\section{Health Insurance Act ( $Z F W)$}

The act covers employed persons against the costs of medical assistance and treatment (G. P., dentist, medicine, hospitalization, etc.).

Compulsorily insured are employed persons who earn agreed wage which is fixed yearly. The voluntary health insurance is open to persons who do not come under the compulsory health insurance (commonly in consultation with the employer). Also compulsorily insured are some senior citizens and pensionable persons. Persons of one household who are dependent on a breadwinner are co-insured free of charge. Employers and employees each pay half of the contribution which is deducted from the wages. The contributions have a fixed maximum.

The professional associations collect the contributions and pay these to the Health Council (Ziekenfondsraad). This body supervises the health insurance funds. Employers and employees are both responsible for the registration with a recognized health fund.

\section{Other schemes}

\section{Supplementary Benefits Act ("Toeslagenwet")}

This act guarantees that the benefits awarded under the ZW, AAW/WAO, NWW and the Disablement Insurance Act for Military Personnel are never below a beneficiary's social minimum by providing a supplementary payment.

Supplementary benefits may be applied for with the professional associations. 


\section{Exceptional Medical Expenses Act ( $A W B Z)$}

The act is a national insurance and applies to anyone who is resident in the Netherlands. It provides insurance against the costs of prolonged nursing and treatment, e.g. in hospitals, psychiatric clinics, nursing homes and institutions for the mentally handicapped. Ambulatory health care such as psychotherapy can be included in the insurance.

The contribution is for account of the employer who pays it to the Tax Department.

The act is implemented by the health insurance funds and by private insurers.

\section{Invalidity}

\section{Disablement Insurance Act (WAO)}

The act covers workers against financial loss due to lasting unfitness for work as a result of sickness or infirmity. A worker who after one year is still unfit for work qualifies for benefit if the degree of incapacity is at least $15 \%$. It is not relevant whether he is incapable of doing his usual work but whether he can perform alternative work. The contribution is the same for all industries and is paid by the employer, who pays the contribution to the professional association.

A limit is set to the wages on the basis of which the contribution is calculated. As the WAO benefit is complementary (see under AAW) no WAO contribution is levied on a certain daily amount which is fixed every year (so-called franchise scheme). A worker who has received sickness benefit (ZW) for 52 weeks need not apply for WAO benefit himself. The professional association will start the procedure. A person who has not received sickness benefit must apply for WAO benefit himself.

The measure of incapacity for work is established by the GMD on their behalf by the medical department of the professional association. If required, besides a GMD medical adviser an employment specialist is called in to establish what kind of work the employee could still do and in what way he can be assisted.

The amount of benefit depends on:

- the degree of incapacity for work (there are 7 "categories");

- the daily wages, i.e. the wages the worker would have earned in his former occupation if he had not been incapacitated for work (the wages have a fixed maximum).

The Disablement Insurance Act is implemented by the professional associations who pay the benefits and check whether the regulations are observed.

Those persons who are partially disabled (less than $80 \%$ ) and who are partially unemployed on certain conditions can claim unemployment benefit or IOAW benefit (see explanation). Again, if the benefit is below the social minimum, a supplementary payment may be applied for. A 7,5\% holiday allowance is awarded over the paid benefit.

\section{General Disablement Benefits Act ( $A A W$ )}

The AAW is a national insurance applying to all residents whereas the WAO applies to employees only. The act makes provision for a basic benefit to be paid in case of loss of income as a result of lasting incapacity for work and provides for benefits in kind (provisions). The latter may range from rehabilitation and retraining to transport facilities.

The AAW benefit, which is a certain percentage of a legal "base", is awarded when the beneficiary has been incapable of working for 52 weeks, provided the measure of incapacity 
is at least $25 \%$. The AAW - unlike the WAO - comprises only 6 categories of unfitness for work. This workers are covered under the WAO and AAW. The WAO benefit supplements the AAW benefit. The benefit is paid as one amount.

The GMD acts as the advisory body in the application procedure. Although the AAW is a national insurance it is implemented by the professional associations.

The Tax Department collects the contribution which is a certain percentage of the wages.

Self-employed persons pay the contribution themselves.

For employees the contribution is paid by the employers. No amount may be deducted from the employees' wages.

\section{Other acts}

\section{General Family Allowances Act (AKW)}

The AKW provides for benefit to be paid per quarter to cover the costs of maintenance of children. All residents of the Netherlands are covered.

Family allowance is also paid when a person is sick or unemployed. The supporting parent should apply for an allowance personally.

Family allowance is paid for one's children, for children from a previous marriage and for adopted and foster children. The act presupposes that parents take care of their children under the age of 16 . On certain conditions older children may also qualify. The contribution is owed in full by the employer who pays it to the Tax Department.

General Widows and Orphans Act ( $A W W$ )

The AWW is another national insurance; it provides three kinds of benefits: widow's pension, temporary widow's pension and orphans' pension (the latter for full orphans only). There is no widower's pension.

Contribution for the AWW is deducted from the wages and is paid to the Tax Department.

General Old Age Pensions Act (AOW)

The act gives the right to an old age pension as soon as the age of 65 has been reached. All residents between 15 and 65 are insured. There is a pension scheme for both married and single persons. If a spouse is under the age of 65 the couple is entitled to supplementary allowance which cannot exceed the basic pension. Contribution for the AOW is deducted from the wages and paid to the Tax Department.

The act is implemented by the Social Insurance Bank.

Source: Social Security in the Netherlands (GAK, June 1987), pp. 6-9. 